\author{
Agnieszka KIJO-KLECZKOWSKA ${ }^{1}$ \\ Monika KOSOWSKA-GOLACHOWSKA ${ }^{2}$ \\ Władysław GAJEWSKI ${ }^{3}$ \\ Katarzyna ŚRODA ${ }^{4}$ \\ Tomasz MUSIAL ${ }^{5}$ \\ Krzysztof WOLSKI ${ }^{6}$
}

\title{
SPALANIE OSADÓW ŚCIEKOWYCH W ODNIESIENIU DO WEGLA I BIOMASY
}

\begin{abstract}
Praca podejmuje problematykę spalania osadów ściekowych, jako priorytetowej metody ich termicznej utylizacji, w odniesieniu do węgla i biomasy. Biorąc pod uwagę istotę problemu narastającej produkcji, a także własności osadów ściekowych i metod ich unieszkodliwiania, z uwzględnieniem oddziaływania na środowisko oraz uregulowań prawnych, obserwuje się obecnie coraz większe zainteresowanie wspomnianą tematyką, widoczne zarówno w literaturze krajowej, jak i światowej. Zbliżona wartość opałowa wysuszonych osadów ściekowych do węgla brunatnego, uzasadnia możliwość wykorzystania tych odpadów jako paliwa energetycznego. W pracy zaprezentowano wyniki badań eksperymentalnych stanowiące analizę porównawczą spalania osadów ściekowych oraz węgla i biomasy. Badania prowadzono zgodnie z planem rotalno-uniformalnym, umożliwiającym określenie oddziaływania rozmiaru paliwa, temperatury w komorze spalania i prędkości napływu powietrza na całkowity czas procesu, temperaturę i czas zapłonu paliwa za pośrednictwem części lotnych, temperaturę maksymalną paliwa oraz czas spalania karbonizatu.
\end{abstract}

Słowa kluczowe: osady ściekowe, termiczna utylizacja, mechanizm i kinetyka spalania paliw

\footnotetext{
${ }^{1}$ Autor do korespondencji: Agnieszka Kijo-Kleczkowska, Politechnika Częstochowska, al. Armii Krajowej 21, 42-201 Częstochowa, kijo@imc.pcz.czest.pl.

${ }^{2}$ Monika Kosowska-Golachowska, kosowska@imc.pcz.czest.pl.

${ }^{3}$ Władysław Gajewski, wladyslaw.gajewski@gmail.com

${ }^{4}$ Katarzyna Środa, katarzynasroda@ imc.pcz.czest.pl.

${ }^{5}$ Tomasz Musiał, musial@imc.pcz.czest.pl.

${ }^{6}$ Krzysztof Wolski, wolski@imc.pcz.czest.pl.
} 


\section{Wprowadzenie}

Zgodnie z ustawą z dnia 14 grudnia 2012 r. osady ściekowe to odpady, określone jako substancje, których posiadacz pozbywa się, zamierza się pozbyć lub też do ich pozbycia się jest zobowiązany. Inaczej charakteryzuje je polska norma PN-EN 12832:2004, według której osady to mieszanina wody i części stałych, oddzielonych od różnego rodzaju ścieków, w wyniku procesów naturalnych lub sztucznych. Zgodnie $\mathrm{z}$ definicją unijną osady ściekowe należy definiować jako biomasę. W nawiązaniu do powyższego niezbędne jest zatem prowadzenie badań eksperymentalnych spalania osadów ściekowych, w odniesieniu do biomasy oraz węgla. $Z$ jednej strony traktowane są one jako odpady, z drugiej natomiast - jako pełnowartościowe paliwo energetyczne, które wysuszone podobne jest kinetyką spalania do węgla brunatnego. Właściwości oraz przebieg procesów termicznych osadów ściekowych, w odniesieniu do paliw węglowych oraz biomasy zaprezentowano, m.in. w pracach [2, 4]. Spośród innych paliw, osady ściekowe wyróżniają się: znacznym uwodnieniem $(92 \div 99,5$ $\%$ ), wysoką zawartością związków organicznych, uzależnioną głównie od rodzaju ścieków oraz zastosowanych procesów podczas obróbki osadów (osady surowe: $75 \div 85 \%$ substancji organicznych w suchej masie (s.m.); osady stabilizowane ok. 50\% substancji organicznych w s.m.), zawartością związków nawozowych, łatwością zagniwania oraz wydzielania odorów, skażeniem bakteriologicznym, możliwością występowania substancji szczególnie szkodliwych dla środowiska naturalnego, w tym również metali ciężkich [1]. Rysunek 1 ilustruje ogólną klasyfikację sposobów zagospodarowania osadów ściekowych w 2010 r. (a) oraz 2012 r. (b) [3]. Jak widać, największy udział procentowy przypada na ich przyrodnicze wykorzystanie, przekształcanie w innym celu oraz składowanie - metod wiodących. Na uwagę zasługuje jednak fakt, iż metody termiczne na przestrzeni rozpatrywanych dwóch lat odnotowały największy wzrost procentowy spośród sposobów zagospodarowania tych odpadów. Specyfika właściwości osadów ściekowych sprawia, że ich utylizacja termiczna nie jest procesem obojętnym dla środowiska, a wynika to m.in. $\mathrm{z}$ emisji: $\mathrm{CO}, \mathrm{SO}_{2}, \mathrm{NO}_{\mathrm{X}}$, pyłów, WWA, dioksyn i furanów, a także możliwości występowania w popiołach skumulowanych ładunków metali ciężkich.

\begin{tabular}{|lr|rr|}
\hline a) & & b) & \\
\hline przyrodnicze wykorzystanie & $\mathbf{3 5 , 5 9 \%}$ & przyrodnicze wykorzystanie & $\mathbf{3 4 , 2 2 \%}$ \\
inne & $\mathbf{2 7 , 4 0 \%}$ & inne & $\mathbf{2 8 , 8 1 \%}$ \\
składowanie & $\mathbf{1 8 , 5 3 \%}$ & składowanie & $\mathbf{1 7 , 6 3 \%}$ \\
magazynowanie czasowe & $\mathbf{1 1 , 0 6 \%}$ & magazynowanie czasowe & $\mathbf{8 , 7 2 \%}$ \\
metody termiczne & $\mathbf{7 , 4 2 \%}$ & metody termiczne & $\mathbf{1 0 , 6 2 \%}$ \\
\hline
\end{tabular}

Rys.1.Metody zagospodarowania osadów ściekowych w: a) 2010 r., b) 2012 r., wg [3]

Fig.1. Methods of sewage sludge management in years: a) 2010; b) 2012, by [3] 


\section{Stanowiska badawcze i metodyka pomiarów}

W celu przeprowadzenia badań zastosowano stanowiska badawcze (wizualizacyjna komora badawcza; stanowisko do badań spalania paliw w strumieniu powietrza) oraz metodykę pomiarów, szczegółowo opisane w pracy [2]. Eksperymenty polegały na wizualizacji przebiegu spalania różnego rodzaju paliw oraz ustaleniu kinetyki i wyznaczeniu mechanizmu procesu, na podstawie rejestracji zmian temperatury $\mathrm{w}$ środku i na powierzchni próbki paliwa oraz ubytku jego masy podczas procesu spalania. Materiał badawczy stanowiły brykiety wykonane z pyłu węgla kamiennego i brunatnego, trzech rodzajów biomasy oraz osadów ściekowych. Osady pochodziły z oczyszczalni ścieków obsługującej dużą aglomerację miejsko-przemysłową. Wstępnie miały one postać kulistych granul uzyskanych bezpośrednio z oczyszczalni ścieków, o zawartości wilgoci poniżej $10 \%$. W celu przygotowania brykietów niezbędne było wcześniejsze zmielenie paliw (w stanie analitycznym) i ich przesianie przez sito poniżej $100 \mu \mathrm{m}$. Wykorzystanie specjalnie skonstruowanej brykieciarki umożliwiło wykonanie próbek paliw o rozmiarach, zgodnie z przyjętym planem rotalno-uniformalnym. Analizę techniczną i elementarną badanych paliw przedstawiono w tablicy 1 .

Tablica 1. Analiza techniczna przybliżona i elementarna badanych paliw

Table 1. Proximate and elementary analyses of tested fuels

\begin{tabular}{|c|c|c|c|c|c|c|c|c|c|}
\hline \multirow{4}{*}{ Typ paliwa } & \multicolumn{4}{|c|}{ Analiza techniczna } & \multicolumn{5}{|c|}{ Analiza elementarna } \\
\hline & $\begin{array}{c}\text { Zawartośćc } \\
\text { wilgoci }\end{array}$ & $\begin{array}{c}\text { Zawartość } \\
\text { części } \\
\text { lotnych }\end{array}$ & $\begin{array}{c}\text { Zawartość } \\
\text { popiołu }\end{array}$ & $\begin{array}{l}\text { Wartość } \\
\text { opałowa }\end{array}$ & $\begin{array}{c}\text { Zawartość } \\
\text { pierw. } \\
\text { węgla }\end{array}$ & $\begin{array}{c}\text { Zawartość } \\
\text { pierw. } \\
\text { wodoru }\end{array}$ & $\begin{array}{c}\text { Zawartość } \\
\text { pierw. } \\
\text { azotu }\end{array}$ & $\begin{array}{c}\text { Zawartość } \\
\text { pierw. } \\
\text { tlenu }\end{array}$ & $\begin{array}{l}\text { Zawartość } \\
\text { pierw. } \\
\text { siarki }\end{array}$ \\
\hline & $\mathrm{W}^{\mathrm{a}}$ & $\mathrm{V}^{\mathrm{a}}$ & $\mathrm{A}^{\mathrm{a}}$ & $\mathrm{Q}_{\mathrm{i}}^{\mathrm{a}}$ & $\mathrm{C}^{\mathrm{daf}}$ & $\mathrm{H}^{\mathrm{daf}}$ & $\mathrm{N}^{\mathrm{daf}}$ & $\mathrm{O}^{\text {daf }}$ & $\mathrm{S}^{\mathrm{daf}}$ \\
\hline & $\%$ & $\%$ & $\%$ & $\mathrm{~kJ} / \mathrm{kg}$ & $\%$ & $\%$ & $\%$ & $\%$ & $\%$ \\
\hline $\begin{array}{c}\text { Zrębki } \\
\text { sosnowe }\end{array}$ & 6,99 & 76,75 & 0,55 & 17631 & 50,90 & 5,75 & 0,00 & 43,34 & 0,01 \\
\hline $\begin{array}{c}\text { Wierzba } \\
\text { energetyczna }\end{array}$ & 6,9 & 76,3 & 1,4 & 16824 & 49,6 & 6,0 & 0,3 & 44,0 & 0,1 \\
\hline $\begin{array}{c}\text { Słoma } \\
\text { pszeniczna }\end{array}$ & 8,42 & 68,29 & 6,10 & 15566 & 50,18 & 5,85 & 0,77 & 43,12 & 0,08 \\
\hline $\begin{array}{c}\text { Osady } \\
\text { ściekowe } \\
\end{array}$ & 4,94 & 51,44 & 36,44 & 12574 & 52,49 & 6,69 & 7,27 & 31,09 & 2,46 \\
\hline $\begin{array}{c}\text { Węgiel } \\
\text { brunatny }\end{array}$ & 13,0 & 45,4 & 7,6 & 22313 & 68,4 & 5,5 & 0,6 & 24,9 & 0,6 \\
\hline $\begin{array}{c}\text { Węgiel } \\
\text { kamienny }\end{array}$ & 8,7 & 26,8 & 18,9 & 21687 & 73,3 & 4,3 & 1,1 & 19,0 & 2,3 \\
\hline
\end{tabular}

\section{Wyniki badań eksperymentalnych}

Rysunki 2 i 3 przedstawiają wizualizację przebiegu procesu spalania analizowanych paliw, w odniesieniu do zarejestrowanych zmian ich temperatury 
oraz masy. Umożliwiają ona wnikliwą interpretację zjawiska na poszczególnych etapach spalania (nagrzewanie, odparowanie wilgoci, odgazowanie i spalanie części lotnych, wypalanie karbonizatu).

a)

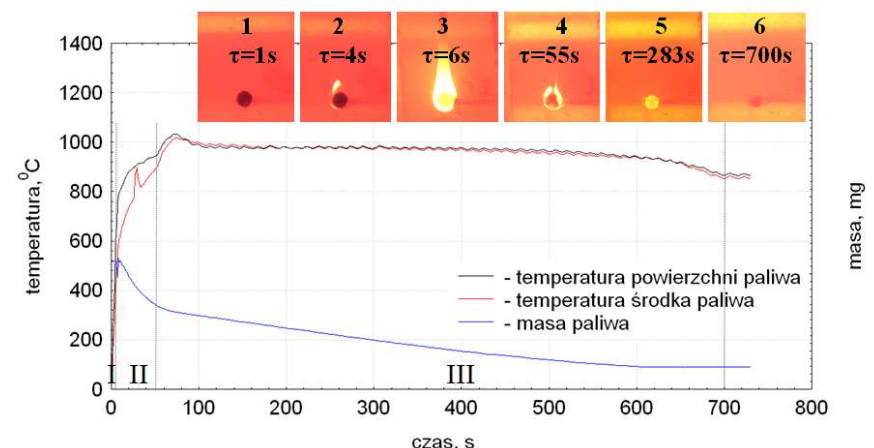

b)

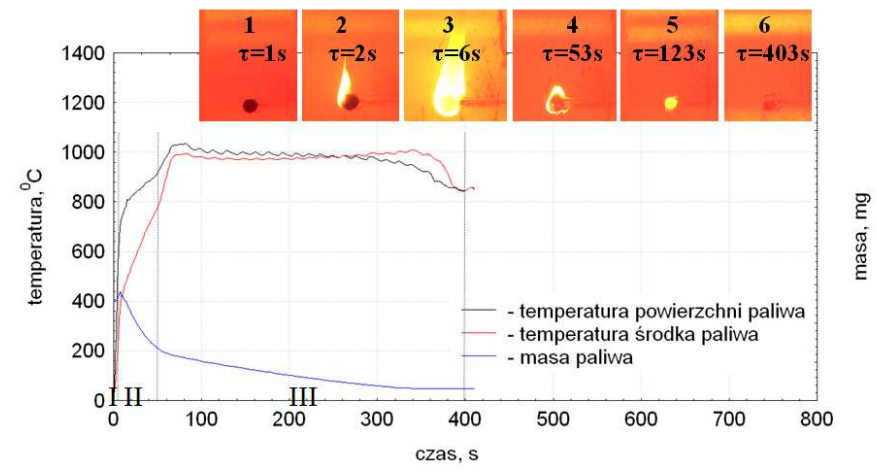

c)

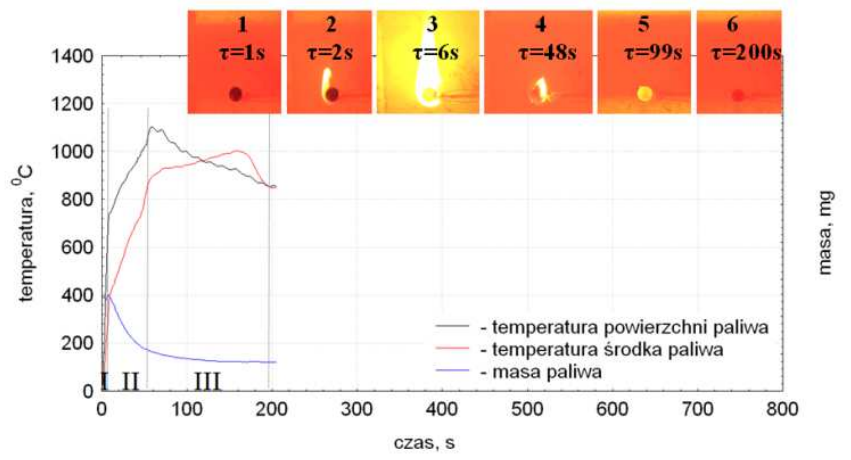

Rys.2. Wizualizacja przebiegu spalania paliw brykietowanych (I - nagrzewanie i odparowanie wilgoci (1), II - odgazowanie i spalanie części lotnych (2-4), III - kontynuacja spalania części lotnych oraz wypalanie karbonizatu (5); popiół (6)): a) węgiel kamienny, b) węgiel brunatny, c) osad ściekowy (badania w komorze wizualizacyjnej; $\mathrm{t}=850^{\circ} \mathrm{C}$ )

Fig.2.Visualization of fuel-briquettes combustion (I - heating and evaporation of moisture (1), II - degassing and volatiles combustion (2-4), III - volatiles combustion and char combustion (5), ash (6)): a) hard coal, b) brown coal c) sewage sludge (test in visualized chamber; $t=850^{\circ} \mathrm{C}$ ) 


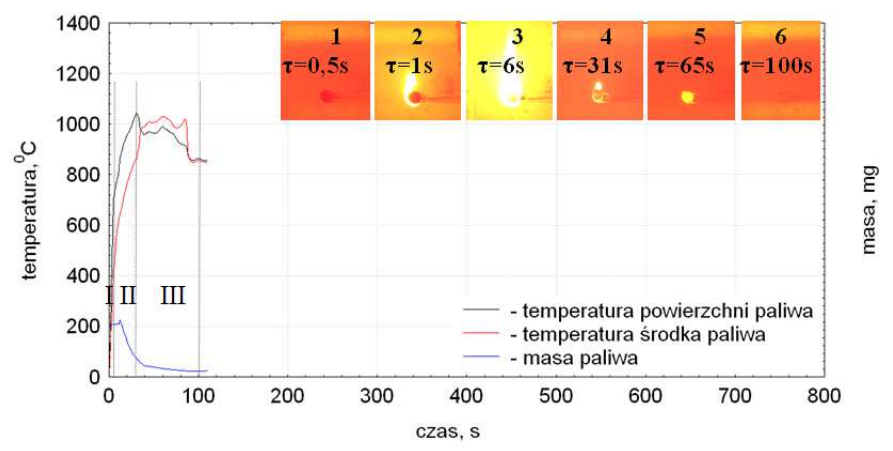

b)
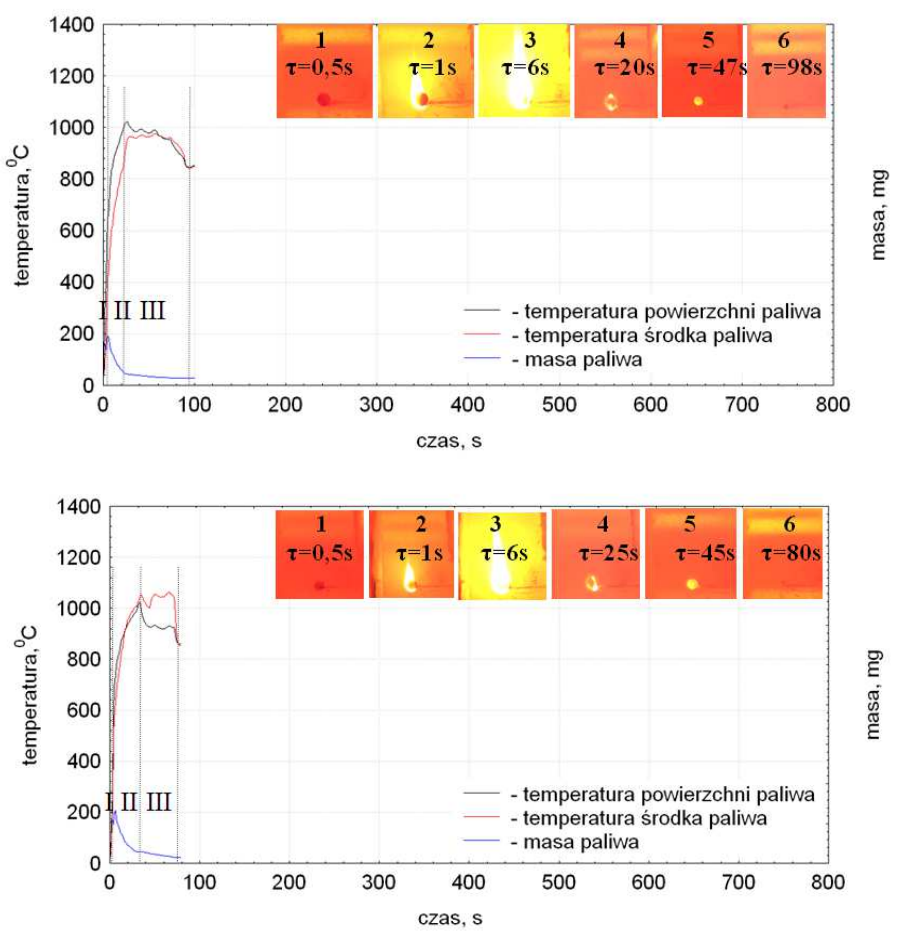

Rys.3. Wizualizacja przebiegu spalania paliw brykietowanych (I-nagrzewanie i odparowanie wilgoci (1), II-odgazowanie i spalanie części lotnych (2-4), III-wypalenie karbonizatu (5); popiół (6)): a) wierzba energetyczna, b) słoma pszeniczna, c) zrębki sosnowe (badania w komorze wizualizacyjnej; $\mathrm{t}=850^{\circ} \mathrm{C}$ )

Fig.3.Visualization of fuel-briquettes combustion (I - heating and moisture evaporation (1), II - degassing and volatiles combustion (2-4), III - char combustion (5), ash (6)): a) energetic willow, b) wheat straw, c) pine shavings (test in visualized chamber; $\mathrm{t}=850^{\circ} \mathrm{C}$ )

Stwierdzono, iż po wprowadzeniu paliwa do komory spalania następuje jego zapłon za pośrednictwem części lotnych wydzielających się intensywnie z pali- 
wa. Wizualna obserwacja procesu wskazuje, że moment ten odpowiada pojawieniu się płomienia palących się części lotnych, a rejestracja zmian temperatury paliwa dowodzi, iż w tym momencie następuje przyspieszenie nagrzewania paliwa. Od chwili zapłonu paliwa za pośrednictwem części lotnych temperatura powierzchni paliwa intensywnie rośnie, by po pewnym czasie uzyskać wartość maksymalną. Zapłon paliwa za pośrednictwem części lotnych prowadzi ponadto do wzrostu temperatury w środku paliwa. Wzrost zawartości części lotnych w paliwie intensyfikuje zatem przebieg procesu spalania. Czas spalania części lotnych wydzielających się z paliwa wyznaczano od momentu pojawienia się płomienia do chwili jego zgaśnięcia. Zaobserwowano, iż najdłuższym etapem spalania paliw jest wypalanie karbonizatu, stanowiące zdecydowany procent całkowitego czasu procesu, zwłaszcza w przypadku paliw wyżej uwęglonych.

Ważnym elementem pracy badawczej było wyznaczenie oddziaływania różnych parametrów procesu na przebieg spalania paliw w strumieniu powietrza. Biorąc pod uwagę rotalno-uniformalny plan badań [5] ustalono następujące wejściowe parametry procesu: $\mathrm{x}_{1}$ - średnica paliwa $(5-10 \mathrm{~mm}), \mathrm{x}_{2}$ - temperatura w komorze spalania $\left(800-900^{\circ} \mathrm{C}\right), \mathrm{x}_{3}$ - prędkość napływu powietrza $(2-3,5 \mathrm{~m} / \mathrm{s}$, przeliczona na warunki wysokotemperaturowe). Każdy pomiar układu planu powtórzono trzykrotnie. Jako wielkości wyjściowe procesu przyjęto: $\boldsymbol{\tau}_{\boldsymbol{s}}$ - całkowity czas spalania $[\mathrm{s}], \boldsymbol{\tau}_{z}$ - czas zapłonu paliwa za pośrednictwem części lotnych $[\mathrm{s}], \boldsymbol{t}_{z}$ - temperaturę na powierzchni paliwa w momencie zapłonu części lotnych $\left[{ }^{0} \mathrm{C}\right], \boldsymbol{\tau}_{\text {tmax }}$ - czas uzyskania temperatury maksymalnej przez powierzchnię paliwa [s], $\boldsymbol{t}_{\max }$ - temperaturę maksymalną na powierzchni paliwa $\left[{ }^{0} \mathrm{C}\right], \boldsymbol{\tau}_{c z l}$ - czas spalania części lotnych [s], $\boldsymbol{\tau}_{k}$ - czas spalania karbonizatu [s]. Rysunek 4 ilustruje przykład metodyki odczytu wspomnianych wielkości wyjściowych podczas spalania osadów ściekowych. W tablicy 2 zestawiono wartości wielkości wyjściowych podczas spalania rozpatrywanych $\mathrm{w}$ badaniach paliw, dla jednego z układów planu rotalno-uniformalnego. Stwierdzono, iż w przypadku osadów ściekowych, spalanie części lotnych stanowi $25 \%$ całkowitego czasu procesu, a wypalanie karbonizatu: 69\%. Rozpatrując pozostałe paliwa uzyskano odpowiednio następujące wartości: dla węgla kamiennego: $11 \%$ i $87 \%$, dla węgla brunatnego: $6 \%$ i $90 \%$, dla zrębków sosnowych: $27 \%$ i $68 \%$, dla wierzby energetycznej: $35 \%$ i $55 \%$ oraz dla słomy pszenicznej: $27 \%$ i $68 \%$. Widać, że w przypadku osadów ściekowych, podobnie do paliw biomasowych, ważnym etapem spalania jest odgazowanie i spalanie części lotnych.

Analizy statystycznej wyników pomiarów, uzyskanych w każdym układzie planu rotalno-uniformalnego dokonano w oparciu o pracę [5]. Obliczone wartości współczynników funkcji aproksymującej całkowity czas spalania różnego rodzaju paliw (tablica 3), wstawione do równania (1), umożliwiły uzyskanie wykresów ilustrujących przebieg ich spalania w różnych warunkach procesu prowadzonego w strumieniu powietrza (rys. 5 i 6). Stwierdzono, iż w przypadku wszystkich rodzajów rozpatrywanych paliw wzrost średnicy brykietów pro- 
wadzi do wydłużenia czasu spalania, w całym przedziale temperatury w komorze spalania oraz prędkości napływu powietrza. Intensyfikacja spalania wraz ze wzrostem prędkości czynnika gazowego, w zakresie większych rozmiarów próbek paliwa, świadczy o przebiegu procesu w obszarze kinetyczno-dyfuzyjnym, z przewagą czynników dyfuzyjnych.

$$
\begin{aligned}
\breve{z} & =b_{0}+b_{01} \cdot \hat{x}_{1}+b_{02} \cdot \hat{x}_{2}+b_{03} \cdot \hat{x}_{3}+b_{11} \cdot \hat{x}_{1}{ }^{2}+b_{22} \cdot \hat{x}_{2}{ }^{2}+b_{33} \cdot \hat{x}_{3}{ }^{2} \\
& +b_{12} \cdot \hat{x}_{1} \cdot \hat{x}_{2}+b_{13} \cdot \hat{x}_{1} \cdot \hat{x}_{3}+b_{23} \cdot \hat{x}_{2} \cdot \hat{x}_{3}
\end{aligned}
$$

Ž- aproksymowana wartość wielkości wyjściowej, $\mathrm{b}_{0}, \mathrm{~b}_{\mathrm{k}}, \mathrm{b}_{\mathrm{kk}}, \mathrm{b}_{\mathrm{qk}}$ - współczynniki.

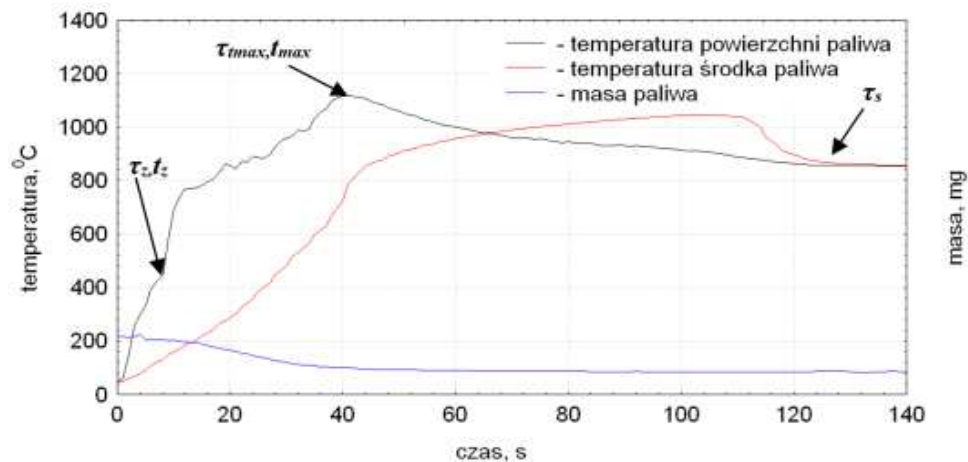

Rys.4. Przykład wyznaczania wielkości wyjściowych spalania paliw stałych (badania prowadzone w strumieniu powietrza) - dane zamieszczone w tablicy 2

Fig.4. The example of determination of output data during combustion of solid fuels (test in air stream) - data are presented in table 2

Tablica 2. Zestawienie wielkości wyjściowych podczas spalania brykietów z paliw stałych Table 2.Output data during combustion of solid fuels briquettes

\begin{tabular}{|c|c|c|c|c|c|c|}
\hline Pomiar/paliwo & $\begin{array}{c}\text { Węgiel } \\
\text { kamienny }\end{array}$ & $\begin{array}{c}\text { Węgiel } \\
\text { brunatny }\end{array}$ & $\begin{array}{c}\text { Osad } \\
\text { ściekowy }\end{array}$ & $\begin{array}{c}\text { Słomapsze- } \\
\text { mapsze- } \\
\text { niczna }\end{array}$ & $\begin{array}{c}\text { Zrębki } \\
\text { sosnowe }\end{array}$ & $\begin{array}{c}\text { Wierzba } \\
\text { energet. }\end{array}$ \\
\hline $\boldsymbol{\tau}_{\boldsymbol{s}}, \mathrm{s}$ & 319,33 & 175,67 & 128,67 & 61,00 & 50,33 & 45,33 \\
\hline $\boldsymbol{\tau}_{\boldsymbol{z}}, \mathrm{s}$ & 5,67 & 6,33 & 8,00 & 2,74 & 2,89 & 4,53 \\
\hline $\boldsymbol{t}_{\boldsymbol{z}},{ }^{0} \mathrm{C}$ & 404,67 & 572,33 & 443,00 & 307,33 & 408,67 & 324,33 \\
\hline $\boldsymbol{\tau}_{\boldsymbol{m a x}}, \mathrm{s}$ & 40,67 & 17,00 & 40,00 & 19,33 & 16,33 & 20,33 \\
\hline $\boldsymbol{t}_{\boldsymbol{m a x}},{ }^{0} \mathrm{C}$ & 1121,96 & 1150,20 & 1114,80 & 1119,48 & 1182,40 & 1007,17 \\
\hline $\boldsymbol{\tau}_{\boldsymbol{c z} \boldsymbol{l}}, \mathrm{s}$ & 35,00 & 10,67 & 32,00 & 16,60 & 13,44 & 15,80 \\
\hline $\boldsymbol{\tau}_{\boldsymbol{k}}, \mathrm{s}$ & 278,67 & 158,67 & 88,67 & 41,67 & 34,00 & 25,00 \\
\hline $\boldsymbol{\tau}_{\boldsymbol{c z} \boldsymbol{l}} \boldsymbol{\tau}_{\boldsymbol{s}}$ & $11 \%$ & $6 \%$ & $25 \%$ & $27 \%$ & $27 \%$ & $35 \%$ \\
\hline $\boldsymbol{\tau}_{\boldsymbol{k}} \boldsymbol{\tau}_{\boldsymbol{s}}$ & $87 \%$ & $90 \%$ & $69 \%$ & $68 \%$ & $68 \%$ & $55 \%$ \\
\hline
\end{tabular}


Tablica 3. Wartości współczynników funkcji aproksymującej czas spalania różnego rodzaju paliw Table 3. The values of coefficients of the approximation function of the combustion time of different kinds of fuels

\begin{tabular}{|c|c|c|c|c|c|c|}
\hline \multirow{2}{*}{$\begin{array}{c}\text { Współ- } \\
\text { czynnik }\end{array}$} & \multicolumn{6}{|c|}{ Wartość współczynnika dla czasu spalania dla paliw: } \\
\cline { 2 - 7 } & $\begin{array}{c}\text { osady } \\
\text { ściekowe }\end{array}$ & $\begin{array}{c}\text { wierzba } \\
\text { energetyczna }\end{array}$ & $\begin{array}{c}\text { zrębki } \\
\text { sosnowe }\end{array}$ & $\begin{array}{c}\text { słoma } \\
\text { pszeniczna }\end{array}$ & $\begin{array}{c}\text { węgiel } \\
\text { kamienny }\end{array}$ & $\begin{array}{c}\text { węgiel } \\
\text { brunatny }\end{array}$ \\
\hline $\mathrm{b}_{00}$ & 125,75 & 43,46 & 50,25 & 61,87 & 323,93 & 179,32 \\
\hline $\mathrm{b}_{01}$ & 40,82 & 11,42 & 11,53 & 15,62 & 100,99 & 53,32 \\
\hline $\mathrm{b}_{02}$ & $-1,31$ & $-1,71$ & 0,18 & $-0,82$ & $-9,50$ & $-1,54$ \\
\hline $\mathrm{b}_{03}$ & $-3,90$ & $-0,17$ & $-2,53$ & $-3,08$ & $-5,08$ & $-17,75$ \\
\hline $\mathrm{b}_{11}$ & $-1,82$ & $-0,39$ & $-1,05$ & $-2,09$ & 4,03 & $-3,43$ \\
\hline $\mathrm{b}_{12}$ & 0,29 & 1,37 & $-0,12$ & 1,62 & $-3,83$ & $-1,00$ \\
\hline $\mathrm{b}_{13}$ & $-2,29$ & $-0,54$ & $-0,79$ & $-0,54$ & $-4,83$ & $-7,50$ \\
\hline $\mathrm{b}_{22}$ & $-2,59$ & 0,79 & $-1,23$ & $-0,44$ & 7,15 & $-4,08$ \\
\hline $\mathrm{b}_{23}$ & $-4,12$ & $-0,04$ & 0,04 & 0,29 & $-1,42$ & 0,58 \\
\hline $\mathrm{b}_{33}$ & $-3,53$ & 0,85 & $-0,52$ & 0,09 & $-5,46$ & $-1,96$ \\
\hline
\end{tabular}
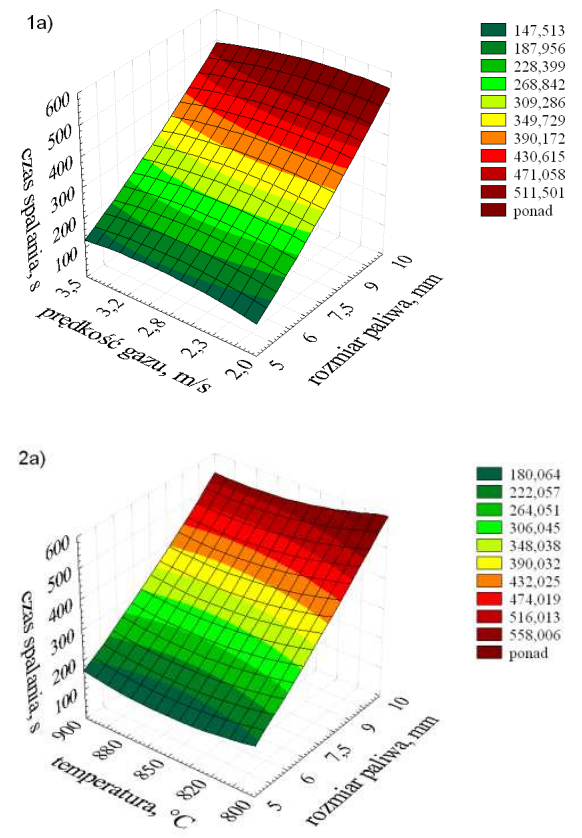

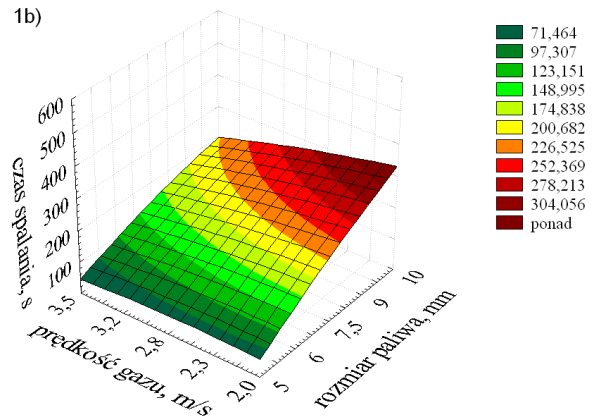

2b)

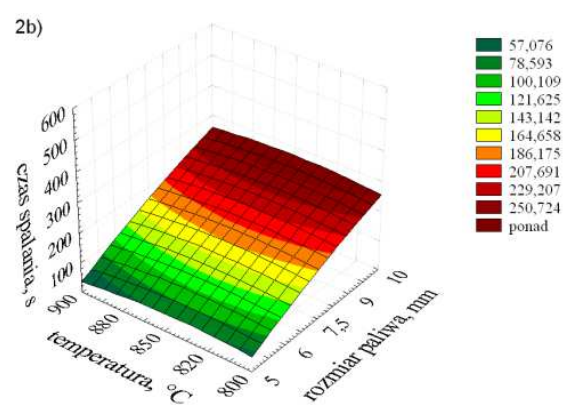

Rys.5. Oddziaływanie na czas spalania brykietów węgla kamiennego (a), węgla brunatnego (b): (1) średnicy próbki paliwa oraz prędkości napływu powietrza, (2) średnicy próbki paliwa oraz temperatury w komorze spalania

Fig.5. Effect of diameter of fuel sample and air velocity (1), diameter of fuel sample and temperature in the combustion chamber (2) on time of briquettes combustion of hard coal (a) and brown coal (b) 


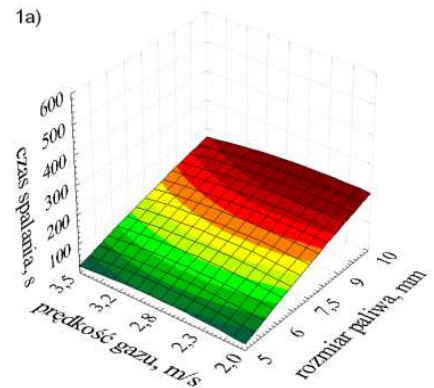

1b)
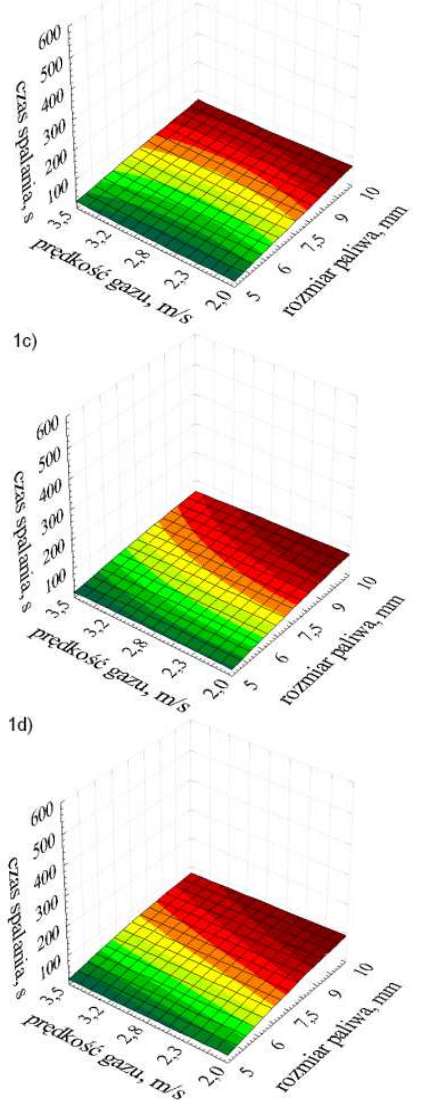
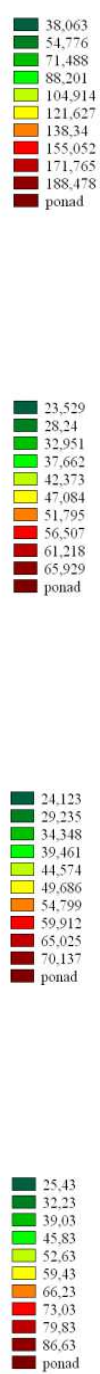
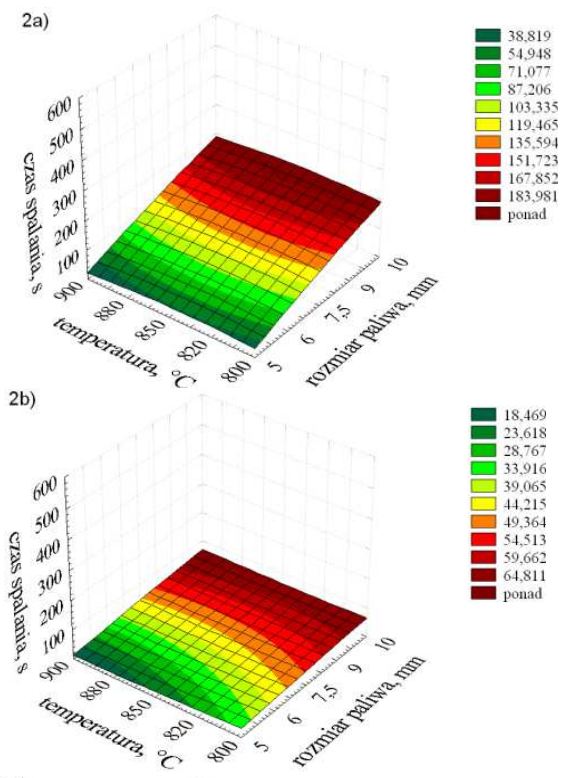

2c)

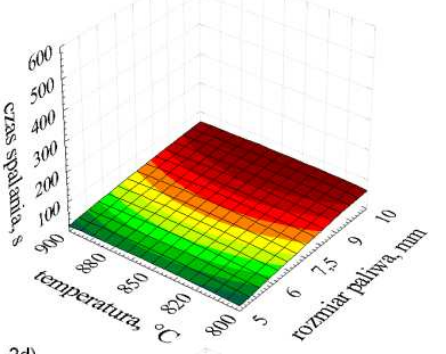

21,946
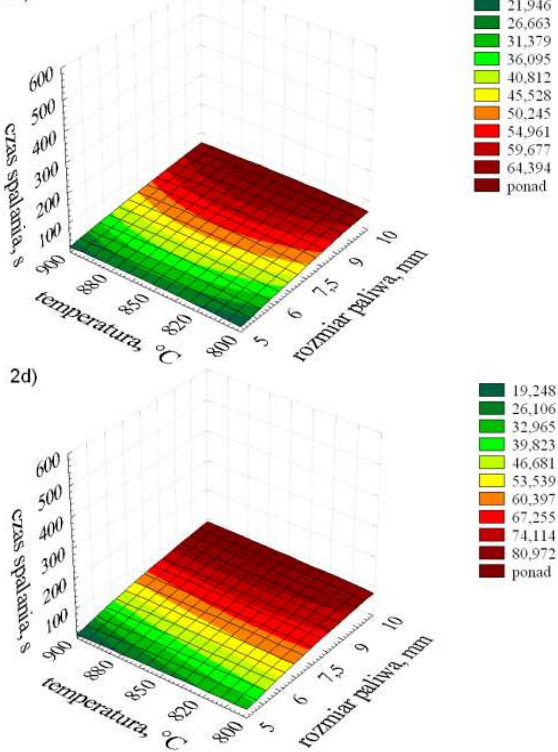

Rys.6. Oddziaływanie na czas spalania brykietów osadu ściekowego (a), wierzby energetycznej (b), zrębków sosnowych (c), słomy pszenicznej (d): (1) średnicy próbki paliwa oraz prędkości napływu powietrza, (2) średnicy próbki paliwa oraz temperatury w komorze spalania

Fig.6. Effect of diameter of fuel sample and air velocity (1), diameter of fuel sample and temperature in the combustion chamber (2) on time of briquettes combustion of sewage sludge (a), energetic willow (b), pine shavings (c), wheat straw (d) 


\title{
4. Wnioski
}

Proces spalania brykietów paliwowych, prowadzony w rozpatrywanych warunkach w strumieniu powietrza, przebiega w obszarze kinetyczno-dyfuzyjnym, z przewagą czynników dyfuzyjnych. Skład i właściwości biomasy oraz osadów ściekowych prowadzą do intensyfikacji przebiegu procesu spalania. W porównaniu do biomasy, osady ściekowe zapalają się płomieniem później i przy wyższej temperaturze. W odróżnieniu od paliw węglowych, o przebiegu procesu spalania osadów ściekowych decyduje nie tylko wypalanie karbonizatu, ale również etap odgazowania i spalania części lotnych.

\section{Literatura:}

[1] Fukas-Płonka Ł.: Kryteria wyboru metod przeróbki i unieszkodliwiania osadów ściekowych, IV Ogólnopol. Konf. Szkol., Starachowice-Kozienice 2013, s. 22-31.

[2] Kijo-Kleczkowska A., Środa K., Otwinowski H.: Study into combustion of sewage sludge as energetic fuel, Arch. Min. Sci., 58 (2013) 1085-1110.

[3] Ochrona Środowiska 2011-2013, GUS, Warszawa 2011-2013.

[4] Środa K., Kijo-Kleczkowska A., Otwinowski H.: Osady ściekowe źródłem energii, Rynek ciepła 2012 (red. H. Kapronia), Wyd. Kaprint, Lublin 2012, s. 265-276.

Projekt zostat sfinansowany ze środków Narodowego Centrum Nauki przyznanych na podstawie decyzji numer DEC-2012/07/B/ST8/03730

\section{SEWAGE SLUDGE COMBUSTION WITH REFERENCE TO THE COAL AND BIOMASS}

\begin{abstract}
S u m m a r y
The paper deals with the problem of sewage sludge combustion as a priority method of thermal utilization, in relation to coal and biomass. Considering the nature of the problem of increasing production, sludge properties and methods of utilization, taking into account the impact on the environment and legislation, there is now a growing interest in mentioned subject, reflected both in the national and world literature. A similar calorific value of dried sewage sludge to brown coal, justifies the possibility to use the sewage sludge as fuel energy. The paper presents the results of experimental studies on comparative analysis of the combustion of sewage sludge, coal and biomass. The investigations were performed according to the rotary-uniform plan, which enables determination of influence of the fuel size, the temperature in the combustion chamber and air velocity on total process time temperature, the both ignition time and temperature of a fuel, maximal temperature of the fuel and combustion time of adsorbents.
\end{abstract}

Keywords: sewage sludges, thermal utilization, mechanism and kinetics of fuels combustion

DOI: $10.7862 / \mathrm{rm} .2014 .42$

Otrzymano/received: 25.05 .2014

Zaakceptowano/accepted: 28.06 .2014 